\title{
Source attribution of climatically important aerosol properties measured at Paposo (Chile) during VOCALS
}

\author{
D. Chand ${ }^{1, *}$, D. A. Hegg ${ }^{1}$, R. Wood ${ }^{1}$, G. E. Shaw ${ }^{2}$, D. Wallace ${ }^{1}$, and D. S. Covert ${ }^{1}$ \\ ${ }^{1}$ Department of Atmospheric Sciences, University of Washington, Seattle, WA, USA \\ ${ }^{2}$ Geophysical Institute, University of Alaska, Fairbanks, AK, USA \\ *now at: Cooperative Institute for Research in the Atmosphere, Colorado State University, Fort Collins, USA
}

Received: 27 June 2010 - Published in Atmos. Chem. Phys. Discuss.: 26 July 2010

Revised: 29 September 2010 - Accepted: 13 October 2010 - Published: 18 November 2010

\begin{abstract}
Measurements of submicron aerosol composition, light scattering, and size distribution were made from 17 October to 15 November 2008 at the elevated Paposo site $\left(25^{\circ} 0.4^{\prime} \mathrm{S}, 70^{\circ} 27.01^{\prime} \mathrm{W}, 690 \mathrm{~m}\right.$ a.s.l. $)$ on the Chilean coast as part of the VOCALS* Regional Experiment (REx). Based on the chemical composition measurements, a receptor modeling analysis using Positive Matrix Factorization (PMF) was carried out, yielding four broad source categories of the aerosol mass, light scattering coefficient, and a proxy for cloud condensation nucleus $(\mathrm{CCN})$ concentration at $0.4 \%$ supersaturation derived from the size distribution measurements assuming an observed soluble mass fraction of 0.53 . The sources resolved were biomass burning, marine, an urban-biofuels mix and a somewhat ambiguous mix of smelter emissions and mineral dust. The urban-biofuels mix is the most dominant aerosol mass component $(52 \%)$ followed by biomass burning (25\%), smelter/soil dust (12\%) and marine (9\%) sources. The average (mean \pm std) submicron aerosol mass concentration, aerosol light scattering coefficient and proxy CCN con-

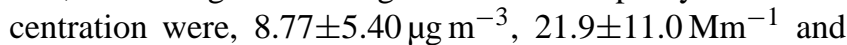
$548 \pm 210 \mathrm{~cm}^{-3}$, respectively. Sulfate is the dominant identified submicron species constituting roughly $40 \%$ of the dry

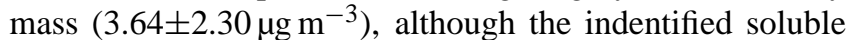
species constitute only $53 \%$ of the mass. Much of the unidentified mass is likely organic in nature. The relative importance of each aerosol source category is different depending upon whether mass, light scattering, or CCN concentration is being considered, indicating that the mean size of aerosols associated with each source are different. Marine aerosols do not appear to contribute to more than $10 \%$ to either mass,
\end{abstract}

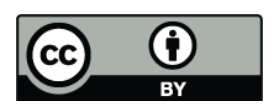

Correspondence to: D. Chand (chand@ cira.colostate.edu) light scattering, or $\mathrm{CCN}$ concentration at this site. Back trajectory cluster analysis proved consistent with the PMF source attribution.

* VOCALS: VAMOS** Ocean-Cloud-Atmosphere-Land Study (VOCALS)

** VAMOS: Variability of American Monsoon System

\section{Introduction}

The impact of aerosols on the radiation balance of the atmosphere, either through direct back scatter to space or through the modulation of the albedo of shallow layer clouds in the marine environment, is well established (Houghton et al., 2001). However, it is difficult to quantitatively deconvolute the impact of various aerosol types; even such a simple dichotomy as anthropogenic and natural, or their climatically relevant properties (e.g., light scattering coefficient $\sigma_{s p}, \mathrm{CCN}$ activity) is obscure. In part, this difficulty arises from the fact that a number of aerosol chemical components that have a strong impact on climate have multiple sources, both natural and anthropogenic. One methodology for addressing this quandary is to examine aerosols in venues in which particular sources, or at least either natural or anthropogenic sources, may be expected to dominate a priori; hence such studies as ACE-1 in the remote Southern Hemisphere (Bates et al., 1998) and TARFOX off of the east coast of the United States (Russell et al., 1999) or, for the particularly tricky issue of sources of CCN activity, the MAST experiment (Durkee et al., 2000). While all of these studies have added much to our understanding of aerosol impacts on climate, none have definitively addressed the issue of aerosol sources even for their extreme venues (cf. Hegg et al., 2009). For venues in

Published by Copernicus Publications on behalf of the European Geosciences Union. 
which one might expect a mix of sources, both natural and anthropogenic, with none dominating, much remains to be done. This is especially true for the impact of aerosols on shallow marine boundary layer clouds off the west coasts of continents.

The impact of aerosols on cloud albedo, in a climatologically significant sense, is conditional upon their impact on the three main semi-permanent subtropical stratocumulus decks of the world due to a combination of cloud extent, frequency, and the cloud type dependent sensitivity of clouds to aerosol albedo modulation (Warren et al., 1988; Platnick and Twomey, 1994). These three subtropical marine stratocumulus regions are located off the west coasts of the United States, Chile/Peru, and southern Africa (Klein and Hartmann 1993). All three venues are known to be impacted by anthropogenic aerosols as well as natural marine aerosols (Durkee et al., 2000; Huneeus et al., 2006; Keil and Haywood, 2003; Allen et al. 2010), and determining the anthropogenic contribution to light scattering and $\mathrm{CCN}$ activity in these regions is critical for understanding aerosol direct and indirect effects on climate.

Differentiation of aerosol sources in these regions is therefore a matter of considerable importance. The southeastern Pacific region off the Peruvian and Chilean coasts is the location of the largest and most persistent stratocumulus deck in the world (Klein and Hartmann, 1993). While little studied, it is known that a complex mix of aerosol sources impact this area (e.g., Huneeus et al., 2006; Tomlinson et al., 2007) and that they influence the microphysical and macrophysical properties of stratocumulus clouds located there (Bretherton et al., 2004; Comstock et al., 2004; Wood et al., 2008; Allen et al., 2010). Furthermore, this region, and the clouds in it, is of substantial importance to tropical climate in general (Yu and Mechoso, 2001), and both regional and global models struggle to accurately represent southeastern Pacific low clouds (Wyant et al., 2010). In an attempt to rectify this situation, the VAMOS Ocean-Cloud-Atmosphere-Land Study Regional Experiment (VOCALS-REx) was conducted in October and November of 2008 (Wood et al., 2010). The goals of VOCALS-REx most pertinent to this study were to obtain a characterization of the physical and chemical properties of the atmospheric aerosol in the coastal region and its transport offshore, to better understand the sources and anthropogenic contribution to this aerosol, and to study its impacts upon the stratocumulus deck.

In this study we will focus upon examining one of the VOCALS hypotheses (Wood et al., 2010), namely: The small [cloud droplet] effective radii measured from space in the coastal region over the Southeast Pacific (SEP) are primarily controlled by anthropogenic, rather than natural, aerosol production, and entrainment of polluted air from the lower free-troposphere is an important source of cloud condensation nuclei (CCN). Specifically, we will focus upon a source attribution for the aerosols sampled at a coastal site in Northern Chile, where satellite sensors are indicating that cloud
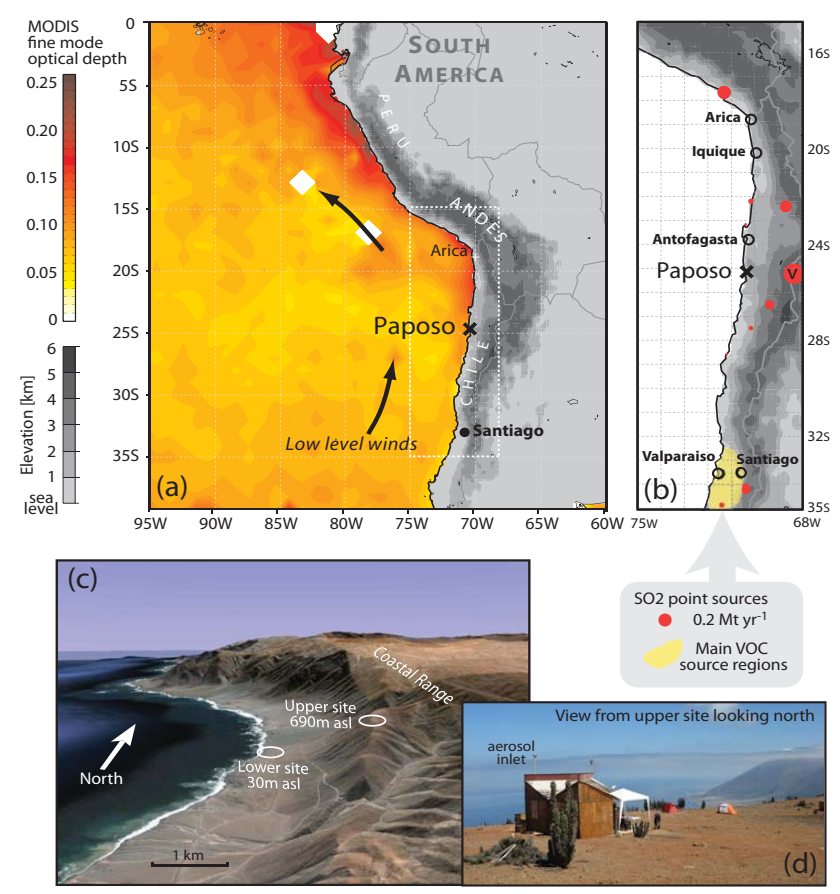

Fig. 1. Location of the aerosol measurements at Paposo, Chile during VOCALS-REx. (a) mean aerosol optical depth at $550 \mathrm{~nm}$ wavelength over ocean from MODIS Terra (colors) and orography (black and white over land). Aerosol retrievals over land indicate primarily coarse mode aerosols, but retrievals are also problematic because of reflective land surface). (b) enlargement of the region of northern/central Chile and southern Peru containing the main anthropogenic and natural sulfur sources. Emissions from the VOCALS emissions database provided by Scott Spak show the strength of $\mathrm{SO}_{2}$ source for most important point sources indicated by area of red circles, with total from shown sources contributing $98 \%$ of total sulfur emissions in the region). Note that the largest $\mathrm{SO}_{2}$ source at $25^{\circ} \mathrm{S}, 68.5^{\circ} \mathrm{W}$ (indicated by the "v") is the Lastarria volcano (all the others shown are copper smelters or power stations). Lastarria is at an altitude of $5500 \mathrm{~m}$ and in predominantly westerly flow. The yellow shaded area shows the main sources of volatile organic compounds (VOCs) that are likely to contribute to secondary organic aerosol formation. (c) Google Earth image looking north showing the coastal mountain range (typically $1000 \mathrm{~m}$ altitude near Paposo) and the location of the aerosol measurement site (upper site). (d) photograph from the elevated site looking north showing the top of the marine boundary layer (commonly at 800-1000 m) delineated by thin clouds.

droplets are anomalously small compared with the remote South Pacific. Analysis shows that the small cloud droplets are explained primarily by anomalously high cloud droplet concentrations in the coastal zone (see e.g. Fig. 1c in George and Wood, 2010). Observations from VOCALS-REx show that these high droplet concentrations are positively correlated with the concentration of accumulation mode aerosols (Bretherton et al., 2010), suggesting that aerosol gradients are responsible for the offshore gradient in droplet effective 
radius, and that it is important to understand the processes driving the formation and transport of $\mathrm{CCN}$ over the Southeast Pacific, and the extent to which anthropogenic impacts play a role. Since the bulk of the aircraft measurements in VOCALS-REx were carried out along the $20^{\circ} \mathrm{S}$ parallel, from the coast $\left(\sim 70^{\circ} \mathrm{W}\right)$ across the cloud droplet effective radius gradient to $85^{\circ} \mathrm{W}$, there is an important need for aerosol characterization measurements closer to the source locations upstream.

In this paper we present aerosol composition, size distribution characteristics, and a source attribution of submicronsized aerosols measured over a month-long period at a rural northern Chilean coastal site during VOCALS-REx. Section 2 describes the measurement location and methodology, followed by the results in Sect. 3 and summary and conclusions in Sect. 4.

\section{Measurement location and methodology}

\subsection{Location}

To satisfy the need for constraints on aerosol properties transported to the offshore regions of the southeastern Pacific, a coastal site at Paposo in northern Chile was selected and was used to make a range of measurements of aerosol physical and chemical characteristics. Figure 1 shows the location of the site. In this study we use measurements only from the upper site $\left(25^{\circ} 0.40^{\prime} \mathrm{S}, 70^{\circ} 27.01^{\prime} \mathrm{W}, 690 \mathrm{~m}\right.$ above mean sea level) located at the top of the hill where all of the aerosol measurements were made. The lower site was situated in the Paposo village (population 300) very close to the coast, where lidar data were taken and radiosonde launches were made. Wood et al. (2010), gives details of the additional measurements taken at the Paposo sites other than those used in this study). Paposo is located $45 \mathrm{~km}$ north of the city of Taltal (population $\sim 10000$ ), and $160 \mathrm{~km}$ south of Antofagasta (population 300000 ), but since prevailing low level winds are from the south, there is little influence of pollution from local population centers. The Paposo upper site is situated in a protected area managed by the Chilean Forest Service (CONAF, http://www.conaf.cl). It is referred to as a "fog oasis" containing several species of unique plant that survive from moisture derived from cloud liquid water in an otherwise extremely dry environment. The primary local aerosol and trace gas emission source in this area is a diesel power plant located at $\sim 2 \mathrm{~km}$ north from the Paposo village at $20 \mathrm{~m}$ a.s.l. This power plant supplies electricity to the village, ore-mines, and ore processing (flotation) plant $10 \mathrm{~km}$ south of Paposo. The estimated $\mathrm{SO}_{2}$ emissions of this power plant are 3000 metric tons $\mathrm{yr}^{-1}$ (Spak et al., 2010), which is only a very small fraction of the estimated emissions from regional copper smelters (Fig. 1). Since measurements were made upwind of the power plant at $\sim 700 \mathrm{~m}$ a.m.s.l., we do not expect a significant contribution to the measured aerosol properties from the Paposo power plant. Thermodynamic weather station data taken at the upper site confirmed that this site remained within the marine boundary layer throughout the measurement period. We expect that local transportation aerosol sources are minimal since the upper site is $2 \mathrm{~km}$ from the nearest road. High time resolution aerosol measurements do not indicate strong and intermittent local sources that could contribute significantly to the submicron mass or light scattering. Overall, the aerosol at the site is considered to be representative of the natural and anthropogenic, regional-scale sources along the coast of Chile that feed the gradients in the SEP mentioned in the introduction.

\subsection{Measurements}

In this paper we describe measurements of submicron aerosol composition, light scattering coefficient, and the aerosol size distribution over the size range from $20-300 \mathrm{~nm}$ diameter. Using these data, a receptor model is employed for source attribution of key aerosol properties. Such models have been long employed to address the general problem of aerosol source attribution (e.g., Cheng et al., 1993; Song et al., 1999; Kim et al., 2004; Chen et al., 2007). Recently, a receptor model using a similar set of observed properties to those we use here was used for source attribution of $\mathrm{CCN}$ impacting the stratocumulus deck off of the west coast of the United States (Hegg et al., 2009). Their model was able to show that three primary source categories (marine, pollution, and biomass burning) contribute significantly to $\mathrm{CCN}$ in the Californian stratus region, and that marine aerosol contributed approximately $50 \%$ to the total $\mathrm{CCN}$.

To characterize the chemical composition of the submicron-sized aerosol, filter sampling was employed using $47 \mathrm{~mm}$ Teflo membrane filters with a $2 \mu \mathrm{m}$ pore size. The substrates have collection efficiencies in excess of $99.99 \%$ for $0.2 \mu \mathrm{m}$ diameter particles and larger. An impactor was employed in front of the filter substrate to limit collection to particles smaller than $\sim 1 \mu \mathrm{m}$ diameter. The duration of the sampling for a particular filter varied from a few hours to $24 \mathrm{~h}$ but was most commonly $\sim 8 \mathrm{~h}$. Table 1 shows the filter times, sample durations and sample volumes, for all 48 filter samples taken. Both day and night samples were acquired, with typically two samples obtained on each day, over the period 19 October to 14 November 2008. After collection, samples were stored at a nominal $4^{\circ} \mathrm{C}$ prior to analysis. The samples were analyzed at the University of Washington in a single week. All substrates were analyzed gravimetrically and then extracted in $10 \mathrm{ml}$ of HPLC water. The extracts were analyzed by standard Ion Chromatography (IC) for anions (both organic and inorganic), Liquid Chromatography-Mass Spectroscopy (LC-MS) for carbohydrates, and Inductively Coupled Plasma - Optical Emission spectroscopy (ICP-OES) for a suite of trace elements (cf., Gao et al., 2003). The suite of 
Table 1. Filter sampling start time, end time, volume sampled and the aerosol loading (weight).

\begin{tabular}{|c|c|c|c|c|c|c|}
\hline Filter \# & Start time (LT) & End time (LT) & Start time (UTC) & End time (UTC) & Sampling Vol $\left(\mathrm{m}^{3}\right)$ & Sampling Mass $(\mu \mathrm{g})$ \\
\hline 1 & 19/10/07:45 & 19/10/09:45 & 19/10/10:45 & $19 / 10 / 12: 45$ & 3.6 & 126 \\
\hline 2 & 19/10/09:50 & $19 / 10 / 21: 25$ & $19 / 10 / 12: 50$ & $20 / 10 / 00: 25$ & 20.28 & 187 \\
\hline 3 & 19/10/21:46 & 20/10/07:45 & $20 / 10 / 00: 46$ & 20/10/10:45 & 17.97 & 218 \\
\hline 4 & 20/10/08:59 & 20/10/19:45 & $20 / 10 / 11: 59$ & $20 / 10 / 22: 45$ & 19.38 & 298 \\
\hline 5 & $20 / 10 / 20: 45$ & $21 / 10 / 07: 45$ & $20 / 10 / 23: 45$ & $21 / 10 / 10: 45$ & 19.8 & 292 \\
\hline 6 & $21 / 10 / 08: 30$ & $21 / 10 / 19: 30$ & $21 / 10 / 11: 30$ & $21 / 10 / 22: 30$ & 19.17 & 291 \\
\hline 7 & $22 / 10 / 08: 32$ & $22 / 10 / 19: 45$ & $22 / 10 / 11: 32$ & $22 / 10 / 22: 45$ & 19.29 & 197 \\
\hline 8 & 23/10/00:12 & $23 / 10 / 07: 45$ & 22/10/03:12 & $23 / 10 / 10: 45$ & 13.59 & 108 \\
\hline 9 & $21 / 10 / 20: 15$ & $22 / 10 / 07: 32$ & $21 / 10 / 23: 15$ & $22 / 10 / 10: 32$ & 20.31 & 250 \\
\hline 10 & $23 / 10 / 09: 25$ & 23/10/19:15 & $23 / 10 / 12: 25$ & $23 / 10 / 22: 15$ & 17.7 & 158 \\
\hline 11 & 23/10/20:05 & 24/10/07:45 & $23 / 10 / 23: 05$ & $24 / 10 / 10: 45$ & 21 & 91 \\
\hline 12 & 24/10/08:34 & 24/10/17:48 & $24 / 10 / 11: 34$ & $24 / 10 / 20: 48$ & 16.62 & 81 \\
\hline 13 & $24 / 10 / 22: 30$ & $25 / 10 / 07: 45$ & 25/10/01:30 & $25 / 10 / 10: 45$ & 16.65 & 17 \\
\hline 14 & $25 / 10 / 09: 22$ & $25 / 10 / 17: 55$ & $25 / 10 / 12: 22$ & $25 / 10 / 20: 55$ & 14.43 & 131 \\
\hline 15 & 25/10/19:02 & 26/10/07:10 & 25/10/22:02 & 26/10/10:10 & 21.84 & 156 \\
\hline 16 & 26/10/10:00 & $26 / 10 / 18: 45$ & 26/10/13:00 & $26 / 10 / 21: 45$ & 14.61 & 115 \\
\hline 17 & $26 / 10 / 19: 50$ & $27 / 10 / 07: 36$ & $26 / 10 / 22: 50$ & $27 / 10 / 10: 36$ & 20.73 & 150 \\
\hline 18 & 27/10/09:20 & $27 / 10 / 20: 45$ & $27 / 10 / 12: 20$ & $27 / 10 / 23: 45$ & 20.55 & 98 \\
\hline 19 & $27 / 10 / 21: 37$ & 28/10/07:00 & 28/10/00:37 & 28/10/10:00 & 16.89 & 141 \\
\hline 20 & 28/10/08:00 & 29/10/07:30 & 28/10/11:00 & 29/10/10:30 & 42.3 & 219 \\
\hline 21 & 29/10/08:27 & 29/10/20:20 & 29/10/11:27 & $29 / 10 / 23: 20$ & 21.39 & 100 \\
\hline 22 & $29 / 10 / 21: 35$ & $30 / 10 / 07: 35$ & 30/10/00:35 & $30 / 10 / 10: 35$ & 18 & 75 \\
\hline 23 & 30/10/09:16 & 30/10/20:00 & $30 / 10 / 12: 16$ & $30 / 10 / 23: 00$ & 19.32 & 109 \\
\hline 24 & $30 / 10 / 20: 45$ & $31 / 10 / 07: 40$ & $30 / 10 / 23: 45$ & $31 / 10 / 10: 40$ & 19.65 & 180 \\
\hline 25 & $31 / 10 / 09: 40$ & 01/11/09:44 & $31 / 10 / 12: 40$ & $01 / 11 / 12: 44$ & 43.32 & 309 \\
\hline 26 & 01/11/10:18 & 01/11/19:30 & 01/11/13:18 & $01 / 11 / 22: 30$ & 16.56 & 263 \\
\hline 27 & 01/11/20:00 & 02/11/07:48 & 01/11/23:00 & 02/11/10:48 & 21.24 & 178 \\
\hline 28 & 02/11/09:43 & 02/11/19:40 & 02/11/12:43 & $02 / 11 / 22: 40$ & 17.91 & 162 \\
\hline 29 & 03/11/00:10 & 03/11/07:15 & $02 / 11 / 21: 10$ & 03/11/10:15 & 12.75 & 109 \\
\hline 30 & 03/11/07:40 & 04/11/08:00 & 03/11/10:40 & 04/11/11:00 & 43.08 & 396 \\
\hline 31 & 04/11/09:18 & 04/11/20:10 & 04/11/12:18 & 04/11/23:10 & 17.94 & 147 \\
\hline 32 & 04/11/22:00 & 05/11/07:40 & 05/11/01:00 & 05/11/10:40 & 17.4 & 114 \\
\hline 33 & 05/11/09:48 & 05/11/19:27 & 05/11/12:48 & $05 / 11 / 22: 27$ & 17.37 & 129 \\
\hline 34 & 05/11/21:40 & 06/11/07:40 & 06/11/00:40 & 06/11/10:40 & 18 & 161 \\
\hline 35 & 06/11/09:00 & 06/11/20:00 & 06/11/12:00 & 06/11/23:00 & 19.8 & 160 \\
\hline 36 & $06 / 11 / 21: 16$ & 07/11/08:15 & 07/11/00:16 & $07 / 11 / 11: 15$ & 17.82 & 113 \\
\hline 37 & 07/11/09:52 & 08/11/09:52 & $07 / 11 / 12: 52$ & $08 / 11 / 12: 52$ & 43.2 & 253 \\
\hline 38 & 08/11/10:45 & 08/11/19:32 & 08/11/13:45 & $08 / 11 / 22: 32$ & 15.81 & 120 \\
\hline 39 & 09/11/00:00 & 09/11/07:00 & 09/11/03:00 & 09/11/10:00 & 12.6 & 104 \\
\hline 40 & 09/11/09:07 & 09/11/19:30 & 09/11/12:07 & $09 / 11 / 22: 30$ & 18.69 & 152 \\
\hline 41 & 09/11/21:02 & 10/11/07:40 & 10/11/00:02 & 10/11/10:40 & 11.04 & 52 \\
\hline 42 & 10/11/10:08 & 10/11/19:31 & 10/11/13:08 & $10 / 11 / 22: 31$ & 16.89 & 98 \\
\hline 43 & 10/11/22:00 & 11/11/07:07 & 11/11/01:00 & 11/11/10:07 & 16.41 & 62 \\
\hline 44 & 11/11/08:30 & 11/11/18:30 & 11/11/11:30 & $11 / 11 / 21: 30$ & 18 & 153 \\
\hline 45 & 11/11/21:43 & $12 / 11 / 07: 45$ & 12/11/00:43 & $12 / 11 / 10: 45$ & 18.06 & 217 \\
\hline 46 & 12/11/09:45 & 13/11/08:31 & 12/11/12:45 & 13/11/11:31 & 38.58 & 434 \\
\hline 47 & 13/11/09:05 & 13/11/19:08 & 13/11/12:05 & 13/11/22:08 & 17.79 & 430 \\
\hline 48 & 14/11/08:00 & 14/11/19:10 & 14/11/11:00 & $14 / 11 / 22: 10$ & 20.1 & 344 \\
\hline
\end{tabular}

species analyzed is given in Table 2 (note that this procedure yields water soluble analytes only).
The size distribution of the aerosol in the diameter range of 20 to $300 \mathrm{~nm}$ was measured every 5 min with a Scanning Mobility Particle Spectrometer (Wang and Flagan 1990) consisting of a Differential Mobility Analyzer (TSI model 3071 
Table 2. Summary of the mean values and standard deviations of the aerosol species masses and other physical parameters observed during the study. Unless otherwise indicated, the units are in $\mu \mathrm{g} \mathrm{m}^{-3}$.

\begin{tabular}{|c|c|c|c|c|c|}
\hline Species & Technique & Mean & Std. Dev. $\sigma$ & $\sigma /$ mean & Used in PMF? \\
\hline Mannitol & $\mathrm{IC}$ & .0056 & .0032 & 0.57 & Yes \\
\hline Levoglucosan & LC-MS & .0007 & .001 & 1.43 & Yes \\
\hline Chloride & IC & .097 & .071 & 0.73 & Yes \\
\hline Nitrate & IC & .016 & .013 & 0.81 & Yes \\
\hline Succinate & IC & .091 & .062 & 0.68 & Yes \\
\hline Sulfate & IC & 3.64 & 2.30 & 0.63 & Yes \\
\hline Oxalate & $\mathrm{IC}$ & .086 & .34 & 3.95 & Yes \\
\hline Aluminum & ICP-OES & .011 & .012 & 1.09 & Yes \\
\hline Calcium & ICP-OES & .048 & .028 & 0.58 & Yes \\
\hline Iron & ICP-OES & .023 & .018 & 0.78 & Yes \\
\hline Potassium & ICP-OES & .04 & .056 & 1.40 & Yes \\
\hline Magnesium & ICP-OES & .033 & .019 & 0.58 & Yes \\
\hline Sodium & ICP-OES & .2 & .15 & 0.75 & Yes \\
\hline Silicon & ICP-OES & .033 & .06 & 1.82 & Yes \\
\hline Manganese & ICP-OES & .0014 & .0011 & 0.79 & Yes \\
\hline Sulfur & ICP-OES & .92 & .63 & 0.68 & Yes \\
\hline Strontium & ICP-OES & .0001 & .00011 & 1.10 & Yes \\
\hline Copper & ICP-OES & .0056 & .0084 & 1.50 & Yes \\
\hline Zinc & ICP-OES & .0049 & .0095 & 1.94 & Yes \\
\hline Total dry mass & Gravimetric & 8.77 & 5.40 & 0.62 & Yes \\
\hline NSS Potassium & Derived & .032 & .051 & 1.59 & Yes \\
\hline NSS Sulfate & Derived & 3.64 & 2.30 & 0.63 & Yes \\
\hline Soluble mass & IC/ICP/Derived & 4.68 & 3.00 & 0.64 & No \\
\hline Aerosol number $20-1000 \mathrm{~nm}\left(\mathrm{~cm}^{-3}\right)$ & SMPS/OPC & 1070 & 770 & 0.72 & No \\
\hline Aerosol number $>50 \mathrm{~nm}\left(\mathrm{~cm}^{-3}\right)$ & SMPS & 667 & 353 & 0.53 & No \\
\hline Aerosol number 70-280 (nm) & SMPS & 508 & 208 & 0.41 & No \\
\hline Aerosol number $>300 \mathrm{~nm}\left(\mathrm{~cm}^{-3}\right)$ & OPC & 52 & 26 & 0.50 & No \\
\hline Aerosol light scattering coefficient $\left(\mathrm{Mm}^{-1}\right)$ & Nephelometer & 21.9 & 11.0 & 0.50 & No \\
\hline
\end{tabular}

DMA), and a Condensation Nucleus Counter (TSI model $3010 \mathrm{CNC}$ ). We also sampled aerosols using an optical particle counter (OPC Model: Climet Cl-150t) in four size channels $(>0.3,0.3-0.5,0.5-1.0,1.0-5.0 \mu \mathrm{m})$. These data were integrated over the filter sampling intervals. Aerosols were passed over a Kr85 source to bring them to a Boltzman equilibrium charge distribution (Wiedensohler 1988). The DMA was operated with sheath and sample air flow rates of $5 \mathrm{~L} \min ^{-1}$ and $1 \mathrm{~L} \mathrm{~min}^{-1}$ respectively. The flows were set with a bubble flow meter to $2 \%$ accuracy, but were not actively controlled. The flow remained constant to one or two percent between visits to the site every few days.

The aerosol submicron light scattering coefficient was measured with an integrating nephelometer (M903, Radiance Research, Seattle) with a measurement wavelength of $0.55 \mu \mathrm{m}$. Airflow through the instrument was set at $5 \mathrm{~L} \mathrm{~min}^{-1}$. Data were averaged over $5 \mathrm{~min}$ intervals and calibration was executed by filling the scattering volume with pure, particle-free carbon dioxide $\left(\mathrm{CO}_{2}\right)$ gas. The instrumental zero was checked daily by sampling filtered, particle-free air. According to the drifts in the zero and calibration we infer that the measured scattering coefficient is accurate to $\pm 1 \mathrm{Mm}^{-1}$, which is approximately $5 \%$ of the mean scattering coefficent measured during the campaign (Table 2).

The receptor model used in this analysis is a version of Positive Matrix Factorization (PMF), a type of factor analysis which places various constraints on the matrix inversion to yield more physically plausible solutions (Paatero and Tapper, 1994). Specifically, the US EPA PMF 3.0 version, which has been widely used in regulatory assessments, was employed.

\section{Results and discussion}

\subsection{Overview of the measurements}

A summary of the measurements, including the mean and standard deviation of the concentrations for each species or parameter measured during the study is given in Table 2. Figure 2 summarizes the aerosol mean/median aerosol size distribution measured during the campaign, and Fig. 3 shows time series of aerosol scattering coefficient, and 


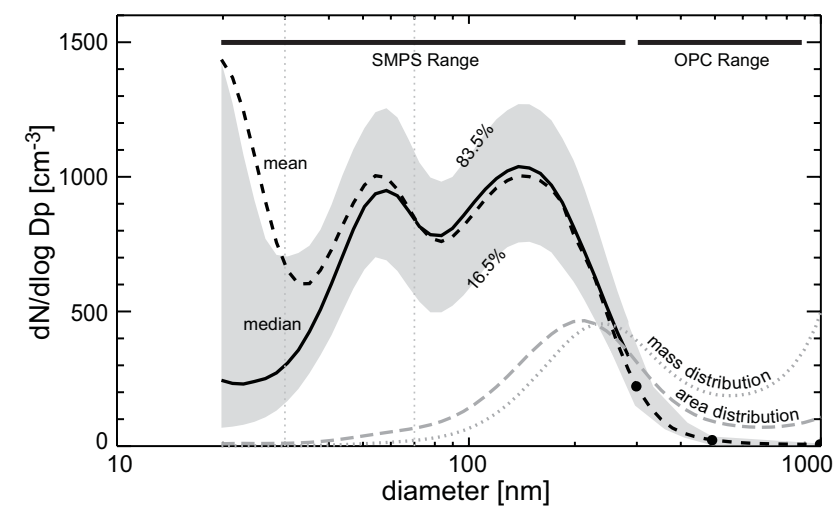

Fig. 2. Mean (dashed, SMPS and OPC) and median (solid, SMPS only) aerosol size distribution from the SMPS (20-280 nm diameter) and OPC (>300 nm diameter) for the period 23 October-15 November 2008. The solid circles show the OPC size distribution for the three submicron size categories $(0.3,0.5$ and $1 \mu \mathrm{m})$ and the fit to these points is used to extend the mean size distribution to cover the entire submicron range. The gray shaded area shows the central $67 \%$ (16.5 and 83.5 percentiles) of the size distribution variability. Also shown are the mass and area distributions (arbitrary ordinate scaling) for the mean size distribution.

aerosol concentrations $(20-35 \mathrm{~nm}, 35-70 \mathrm{~nm}, 70-280 \mathrm{~nm}$, and $>300 \mathrm{~nm}$ ) from the SMPS and OPC. The mean aerosol size distribution (Fig. 2) is characterized by three number modes, with a hint of an additional mode in the supermicron range. The number distribution is dominated by accumulation and Aitken modes, with the Aitken mode, here defined as particles with dry diameters $35-70 \mathrm{~nm}$, contributing approximately half of the total aerosol number concentration (Table 2, Figs. 2 and 3). Variability in the size distribution is greatest at small sizes (Fig. 2 and Table 2) which is commonly (though not always) an indicator that in situ particle production (e.g., Shaw, 2007) is taking place sporadically. The accumulation mode aerosol concentration, at some $700 \mathrm{~cm}^{-3}$ in the mean, is indicative of a moderately polluted environment, and the aerosol mass (Fig. 3c) and scattering coefficient (Fig. 3a) are consistent with values for locations influenced by regional air pollution. For example, these observations of accumulation mode aerosols $\left(\sim 700 \mathrm{~cm}^{-3}\right)$ over the west coast of South America are in the lower end of the range of aerosols $\left(300-10000 \mathrm{~cm}^{-3}\right)$ over the Atlantic marine environment west of Africa (Koponen et al., 2002).

There is a good degree of correlation between the submicron scattering coefficient, the accumulation mode concentration, the aerosol volume, and the mass loading for the submicron aerosols (compare panels in Fig. 3), with only a weak diurnal cycle in these parameters. The smallest particles (20$35 \mathrm{~nm}$ ) do exhibit a significant diurnal modulation (note the timing of the peaks in Fig. 3b) with concentrations peaking at night. Further investigation of the diurnal cycle is beyond the scope of this study. Figure 2 also gives an indication that
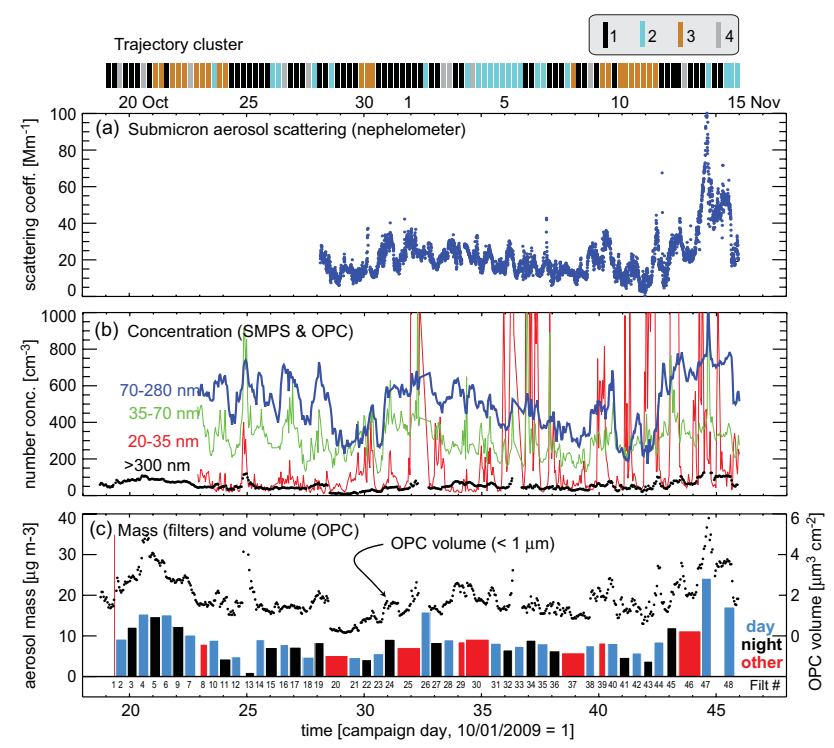

Fig. 3. Time series of (a) scattering coefficient for submicron aerosols from the nephelometer; (b) aerosol concentrations for the size ranges $20-35 \mathrm{~nm}$ (nominally the nucleation mode), $35-70 \mathrm{~nm}$ (nominally the Aitken mode), 70-280 nm and $>300 \mathrm{~nm}$ from the SMPS and OPC; (c) gravimetrically-derived aerosol mass loading (bars, left axis) and submicron aerosol volume from the OPC (right axis). The filters sampling times dictate the width of the bars, and the colors indicate whether the sample was taken during the day (sampling start time 06:00-12:00 h local, end time 17-23 hr local), night (sampling start time 17:00-23:00 h local, end time 06:0012:00 h local), or other (all other samples, mostly ones sampling an entire day). The filter number (corresponding to Table 1) is indicated below the bars. At the top of the figure is shown the trajectory cluster number for the back-trajectory classification presented in Sect.3.3 and shown in Fig. 10.

an additional supermicron aerosol mode is present, but in this study we focus only on the properties of the submicron sized aerosols.

Over $40 \%$ of the total dry aerosol mass is, on average, attributable to sulfate (Table 2), making it by far the most important resolved chemical species present. The time variation of the sulfate and total mass concentrations, shown in Fig. 4, further illustrate a close connection $(r=0.94)$ between the two parameters. On the other hand, using plausible assumptions about the molecular forms of the species shown in Table 2 (e.g., measurements offshore suggest an ammonium to sulfate molar ratio of about 0.25 in the accumulation mode; Tomlinson et al., 2007), it should be kept in mind that only about $\sim 50 \%$ of the total mass has been speciated. Other measurements taken nearby during VOCALS (Hawkins et al., 2010) suggest that in large part this unspeciated mass is organic in nature. Other chemical species also show interesting temporal patterns. Time series for $\mathrm{Al}, \mathrm{Cu}$ and oxalate, common components of mineral dust, smelter emissions and biomass burning, respectively, are shown in 


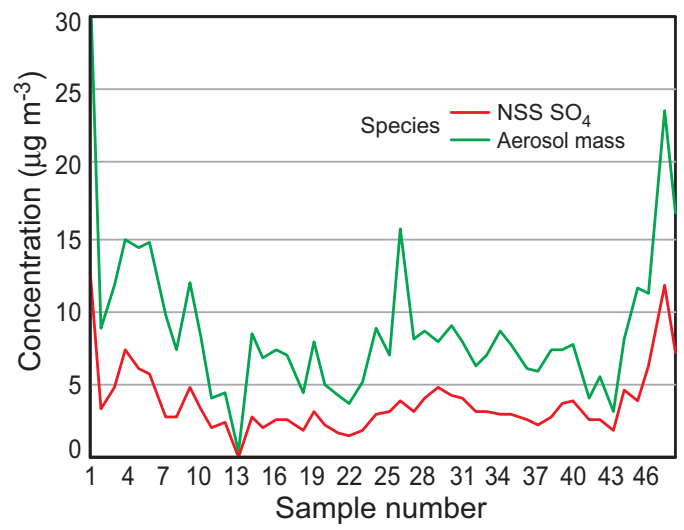

Fig. 4. Time series of the aerosol dry mass and NSS sulfate concentration over the study period.

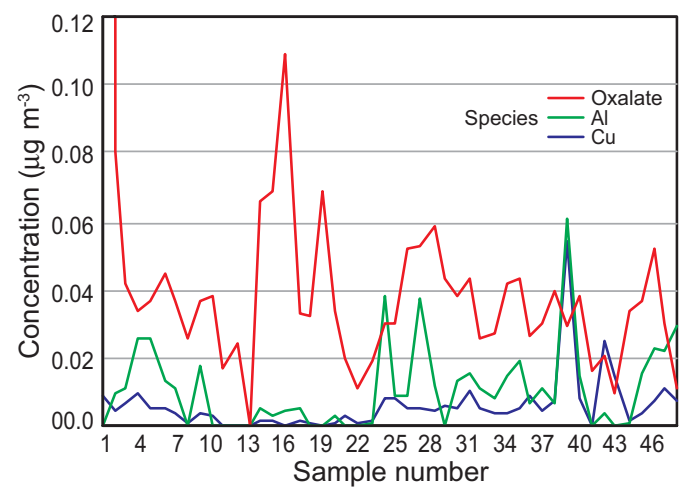

Fig. 5. Time series of oxalate (red), aluminum (green) and copper (blue) over the study period. The date and time of filter sampling is shown in Table 1.

Fig. 5. The high covariance of the $\mathrm{Cu}$ and $\mathrm{Al}$ is noteworthy and will be discussed further in the course of presenting the PMF analysis.

\subsection{PMF results}

The PMF model was run on the 22 chemical species indicated in Table 2 for the 48 filter samples acquired over the course of the study. We initialized between 3 and 6 factors but found that the best solution in terms of a comparison of the $\mathrm{Q}$ parameter (a modified $\chi^{2}$ fit parameter) to theoretical expectations (cf. Reff et al., 2007) and the physical interpretability of the factors was given by a four factor, or source category, interpretation. The solution was further refined by a moderate rotation of the source and strength matrices by setting the Fpeak parameter to 0.3. The FPeak is an important parameter which controls the rotational freedom of the possible solutions (Paatero et al., 2002). The species loadings for the four-factor solution are given in Fig. 6.

Interpretation of the factor loadings shown in Fig. 6 is perhaps the most challenging aspect of PMF analysis (the or-

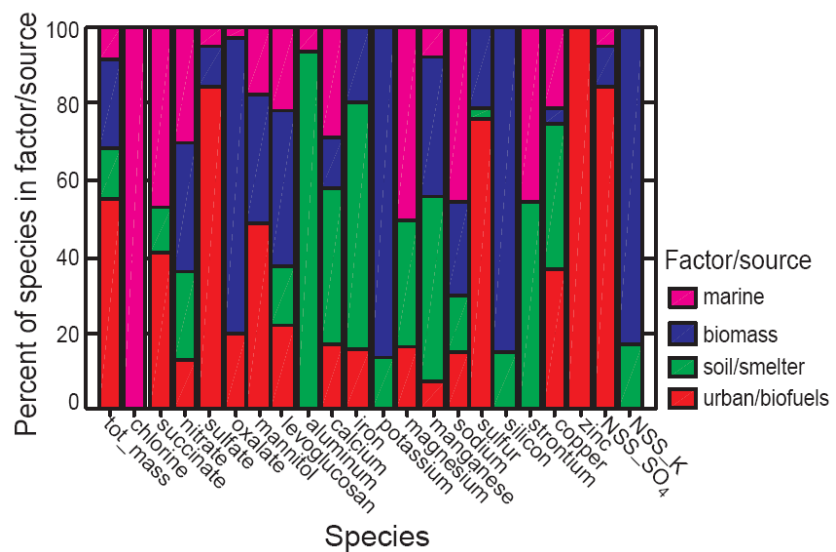

Fig. 6. PMF source profiles for the Paposo aerosols.

der of presentation in the figure is arbitrary). The first factor shown in the legend, marine, is so designated based on the very high loadings of $\mathrm{Cl}, \mathrm{Na}$, and $\mathrm{Mg}$, all well known sea salt constituents. Its interpretation as a marine source category is unambiguous. The second factor or source, biomass, has the highest loadings of oxalate, K, non sea salt (NSS) $\mathrm{K}$ and levoglucosan, the latter two (and implicitly $\mathrm{K}$ since most of the K is NSS-K) being well-known biomass burning markers and oxalate itself is a common biomass burning emission (e.g., Gao et al., 2003, Hegg et al., 2008). More surprising is the high loading of Si though substantial loadings of this element in biomass burning factors have been previously reported (e.g., Artaxo et al., 1998; Maykut et al., 2003; Jimenez et al., 2006), possibly in part due to soil dust re-suspension and in part due to $\mathrm{Si}$ incorporated into some plant species. Nevertheless, this factor also has a relatively clear attribution. The fourth factor, on which virtually all of the zinc, most of the NSS sulfate and the largest fraction of the mannitol is loaded would normally be a clear candidate for an urban, anthropogenic source. However, it also has substantial loadings of succinate and levoglucosan, suggesting that both industrial and biomass burning emissions are convoluted together in this source, as is characteristic of some cities in Siberia and India where residential heating is significantly biofuel based (e.g., Gustafsson et al., 2009; Rengarajan et al., 2007), as is the case in Chile (Scott Spak, personal communication, 2010). Alternatively, the industrial and biomass burning sources, while distinct, could lie along similar transport paths to the receptor site and the emissions could be mixed during such transport. We tentatively designate this source as "urban/biofuels" and will explore the issue further below. The third factor is also somewhat ambiguous. It is loaded most heavily by $\mathrm{Al}, \mathrm{Fe} \mathrm{Mn}$ and $\mathrm{Ca}$, all well known mineral dust components (Artaxo et al., 1998; Nicolas et al., 2008; Kumar and Sarin, 2009) but also has substantial loadings of $\mathrm{Cu}$ and $\mathrm{Sr}$, as might be expected from mining and smelting operations. Possibly, the higher metal loadings 
are indicative of soil contamination from resuspended mine tailing or other forms of soil contamination from smelter operations (cf., Kelm et al., 2009; Gidhagen et al., 2002). In any case, we conservatively identify the factor as a joint soil dust smelter source. It is noteworthy that it is the urban/biofuels source which is the dominent component of the total dry aerosol mass.

Given the source profiles shown in Fig. 6, it is possible to calculate the source attribution of the aerosol properties of interest, namely aerosol mass, light scattering coefficient, and $\mathrm{CCN}$ activity. For aerosol mass and light scattering, the procedure is straightforward (though it should be noted that in the case of mass the PMF analysis was recalculated with total mass removed as an input species to ensure that the factor resolution was not significantly impacted by this component). To arrive at the contribution of each source to the mass or light scattering at each site, regressions of the mass or light scattering coefficient for each sample onto the normalized factor source contribution for each factor for each sample are made. The regression coefficients are then multiplied by the normalized source contributions, sample by sample, to arrive at the contribution of each source to the respective aerosol property for each sample.

While the CCN source attribution follows the same general procedure, the $\mathrm{CCN}$ activity must first be estimated from the size distribution data. To convert the aerosol size distribution measurements to the number concentration active at a particular supersaturation, we have used the well known empirical parameterization of Fitzgerald (1973), which is in good agreement with standard Kohler theory. In addition to the size distribution data, this approach requires an estimate of the aerosol soluble fraction. Based on the chemical composition analysis as shown in Table 2, we find a fairly constant soluble fraction for the measured aerosol of $0.53 \pm 0.11$ over the duration of the experiment. The Aitken mode may be chemically different with respect to soluble mass fraction than the accumulation mode from which the soluble fraction was derived. However, even if the slope of the Aitken mode is steep in the critical range, cumulative number concentration (surogate $\mathrm{CCN}$ ) will not change markedly with a change in critical diameter, i.e., the integration limit, due to varying soluble fraction at or near this size.

For the conditions in the stratocumulus offshore of Paposo, and indeed for stratocumulus in general, a reasonable average supersaturation would be around $0.4 \%$ (cf. Glantz et al., 2003; Martin et al. 1994). Calculating the minimum or critical activation diameters for $0.4 \%$ supersaturation and the observed soluble fractions yields a mean value of $69 \pm 0.5 \mathrm{~nm}$ (mean $\pm \mathrm{SD}$ ). The low variance of the mean suggests the assumption of a constant critical diameter is reasonable. Hence, in the absence of directly measured CCN properties, we have used the cumulative number concentration above $70 \mathrm{~nm}$ diameter (see Table 2) from the SMPS as a surrogate for the $\mathrm{CCN}$ concentration active at $0.4 \%$ supersaturation. As the OPC particles in the range $(<1 \mu \mathrm{m})$ that is the (a)

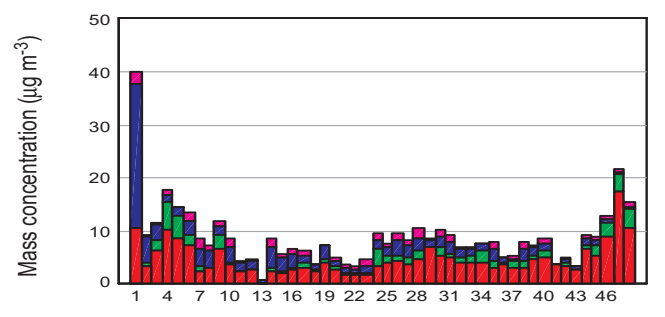

(b)

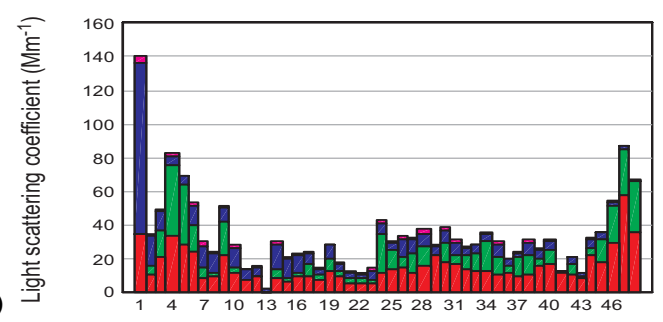

(c)

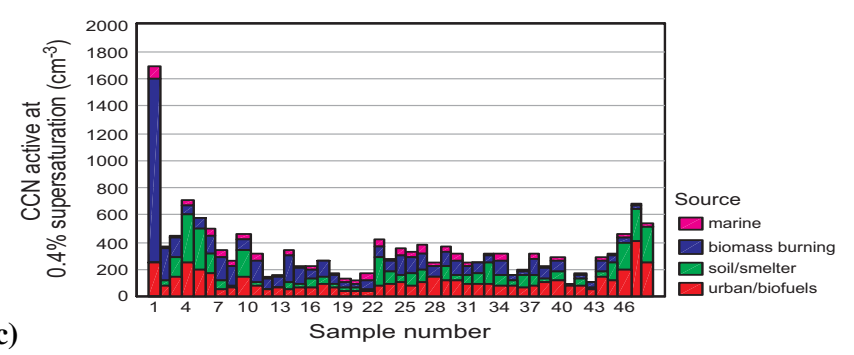

Fig. 7. (a, top) Source contributions to aerosol mass for each of the samples; (b) PMF source contributions to the light scattering coefficient sp; (c) PMF source contributions to the CCN concentration active at $0.4 \%$ supersaturation.

focus of this study are a small fraction of the SMPS number and are not important for other reasons, i.e., they are hardly giant CCN, (see Table 2 and Figs. 2 and 3), we do not include the OPC data in this calculation. These concentrations are used in the regression analysis (see above) to determine the fractional contribution of the different source categories to the total CCN.

The contributions of the four source categories to the aerosol mass, light scattering coefficient and $\mathrm{CCN}$ concentration active at $0.4 \%$ supersaturation to each of the samples acquired during the study are shown in Fig. 7a, b and c, respectively. Because the samples were taken sequentially and roughly at equal intervals, the sequence of samples approximates a time series for the study period (19 October through 14 November, the dates of the first and last samples). There is substantial coherence between the time series of the three parameters, all showing, for example, peaks in the impact of the urban/biofuels source at the beginning and end of the study, with a slight additional maximum near the middle. However, the differential impact of the sources on the three aerosol properties can be more clearly seen by examining the average contributions of the sources to the properties over all the samples. These average contributions are shown in 


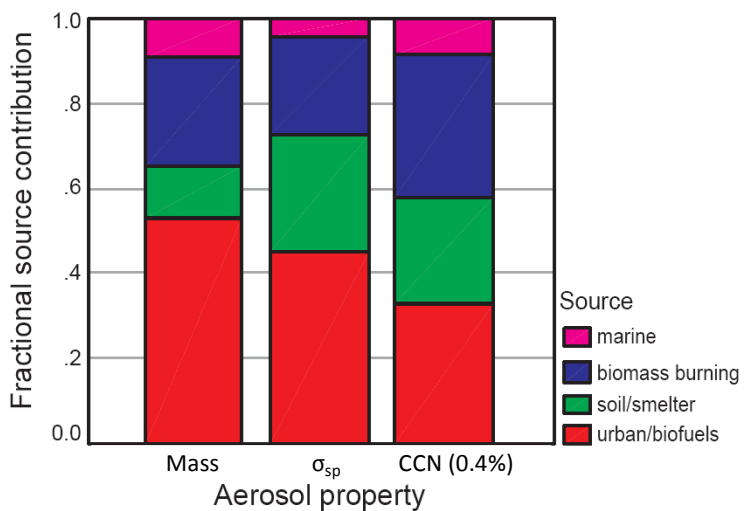

Fig. 8. Fractional contribution of each source to each of the three aerosol properties examined.

Fig. 8. It can be seen that the different properties - which essentially correspond to different moments of the aerosol size distribution (see also Fig. 2) - are impacted differently by the various sources, with the soil dust/smelter and biomass burning sources having a higher contribution to variables that depend upon lower order moments like light scattering coefficient and CCN concentration than to mass. Conversely, the urban/biofuels source that contains most of the sulfate decreases with decreasing moment of particle size. This is not particularly surprising given that the urban/biofuels factor is most prominent in samples with higher mass but not necessarily higher $\mathrm{CCN}$ number. Indeed the linear correlation between the urban/biofuels factor scores (loadings on each sample) and the mass mean diameter (derived from the number concentration $>70 \mathrm{~nm}$ and the mass as per Table 2) reveal that the correlation for the urban/biofuels factor was significantly higher than for any other factor. It is also noteworthy that the $\mathrm{CCN}$ concentration is most impacted by biomass burning, with a similar contribution from the urban/biofuels factor, in turn suggesting that number concentration per unit mass is higher for biofuels than for the other sources, consistent with the lowest correlation being between the urban/biofuels scores and the mass mean diameter. The final generally noteworthy aspect of Fig. 8 is the fact that the marine source contributes less than $10 \%$ to any of the aerosol properties, in accord with the polluted nature of the Paposo site. This contrasts with the results from Hegg et al. (2009) in the Californian coastal region, where similar particle concentrations were observed but where the contribution of marine aerosols to CCN concentration was closer to $50 \%$.

A final aspect of the PMF analysis which needs to be examined is the ability of the PMF sources to reproduce the observations upon which they are based. To this end, the sum of the contributions of each source to each aerosol property for each of the samples is calculated and compared for each respective, measured aerosol property. To do this we regress the PMF predicted property onto the observed property. The regression for mass is shown in Fig. 9a and reveals
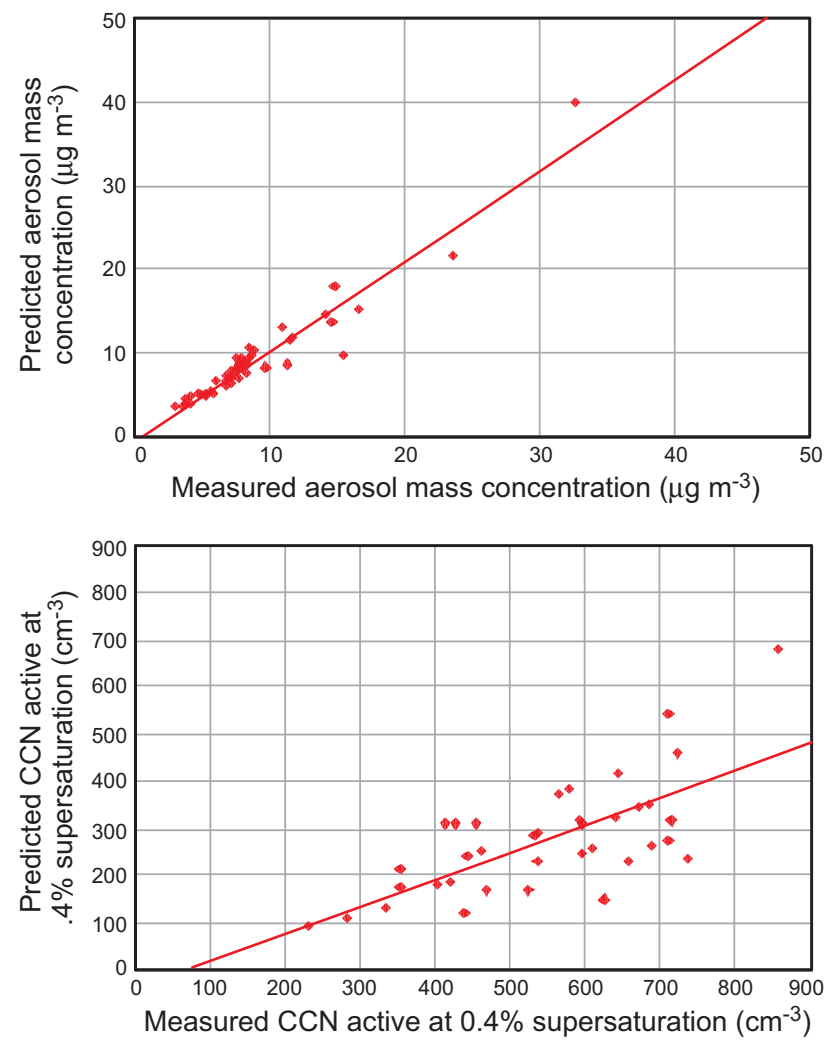

Fig. 9. (a, top): Regression of the total mass predicted by PMF onto the observed total masses; (b, bottom) regression of the PMF predicted $\mathrm{CCN}$ concentration active at $0.4 \%$ supersaturation onto those calculated from the size distribution and composition measurements.

excellent agreement with an $r^{2}$ value of 0.93 and only a very slight bias (slope $=1.08 \pm 0.05$, intercept $=0.6 \pm 0.5$ ). The comparison of scattering coefficient is slightly worse (e.g., $R^{2}=0.84$ ) but is nevertheless quite good. The comparison of CCN, however, reveals a significant discrepancy. This regression is shown in Fig. $9 \mathrm{~b}$ and has a quite modest $R^{2}$ of 0.5 , i.e., only half of the observed variance is being explained by the receptor model. In addition, the model appears to only account for about half of the observed $\mathrm{CCN}$ concentration. Because of the number of additional assumptions made in the derivation of the CCN (e.g., internally mixed aerosol), which essentially inject noise into any physical relationship between $\mathrm{CCN}$ and any other variable, it is not entirely surprising that the model performs with less skill for this aerosol property. Furthermore, as with most such receptor models it is based on aerosol mass, which will tend to have a different variance structure than aerosol number. Indeed, the fall off in $R^{2}$ value with lowering moment of the distribution function, the light scattering value being intermediate to those for mass and number, is in accord with this. Nevertheless, it is also possible, given that the model $\mathrm{CCN}$ predictions are biased low, and explain only about $50 \%$ of the CCN concentration, that one or more sources of $\mathrm{CCN}$ have not been 
resolved by the model. Secondary production is a distinct possibility, and has been documented as an important factor in similar scenarios (e.g., Furutani et al., 2007). Furthermore, such production of additional particles is in accord with the increase in variance of number concentration with smaller particle size alluded to above. It would be expected to impact the number concentration most strongly but scarcely impact the mass, in accord with the above analysis.

\subsection{Back trajectory cluster analysis}

To test the plausibility of the PMF source attribution, back trajectory cluster analysis was conducted for the entire sampling period and each of the samples analyzed was assigned to a particular cluster. The Hysplit IV model (Draxler and Rolph, 2003) was employed and $72 \mathrm{~h}$ back trajectories starting at $25^{\circ} \mathrm{S}, 71^{\circ} \mathrm{W}$ and $400 \mathrm{~m}$ above sea level were run every $6 \mathrm{~h}$ (ending at 06:00, 12:00, 18:00, 24:00 UTC) over the sampling period, to give a total of 108 trajectories over the 27 days from 19 October to 14 November 2008. This location was chosen to be slightly west of the actual geographic location of Paposo $\left(\sim 70.5^{\circ} \mathrm{W}\right)$ because the model terrain is rather smoothed in this region due to strong orographic gradients, and we wanted to ensure that the final trajectory location is truly representative of the marine boundary layer. We use the NCEP GDAS meteorological data including model vertical velocity to determine the trajectory motion. A cluster analysis was then performed on the resulting back trajectory set (e.g., Toledano et al., 2009) and a four cluster solution was found. Increasing the cluster number beyond four did not significantly increase the amount of variance explained. The mean trajectories for the four clusters are given in Fig. 10. Most of the trajectories $(\sim 90 \%)$ indicate flow from the south, which is expected since the low-level flow (i.e. in the MBL) is almost universally from the south in this region due to the existence of the near-permanent subtropical high at $30^{\circ} \mathrm{S}, 90^{\circ} \mathrm{W}$ during the Austral spring season (Garreaud and Muñoz 2005, George and Wood 2010). As Fig. 10a shows, a major difference between the three most common southerly flow clusters is the northward wind speed, with cluster 3 being the fastest, cluster 1 being intermediate, and 4 having the slowest northward motion.

The subsidence rates (Fig. 10b) for the dominant southerly trajectories show a significant diurnal cycle in the final $24 \mathrm{~h}$. The rate, which is most intense in North Chile (north of $30^{\circ} \mathrm{S}$ ), is associated with propagating waves generated from dry convection on the Andes slopes (Garreaud and Muñoz, 2004; Wood et al., 2009). Observations and ECMWF analyses (Wood et al., 2009) show that the wave amplitude close to the Chilean coast is significantly diminished to the south of $30^{\circ} \mathrm{S}$, which we think explains the behavior of the southerly trajectories in the final $24 \mathrm{~h}$ before arriving at Paposo. This conclusion is supported by the persistent diurnal cycle throughout the $72 \mathrm{~h}$ in the subsidence rate in the

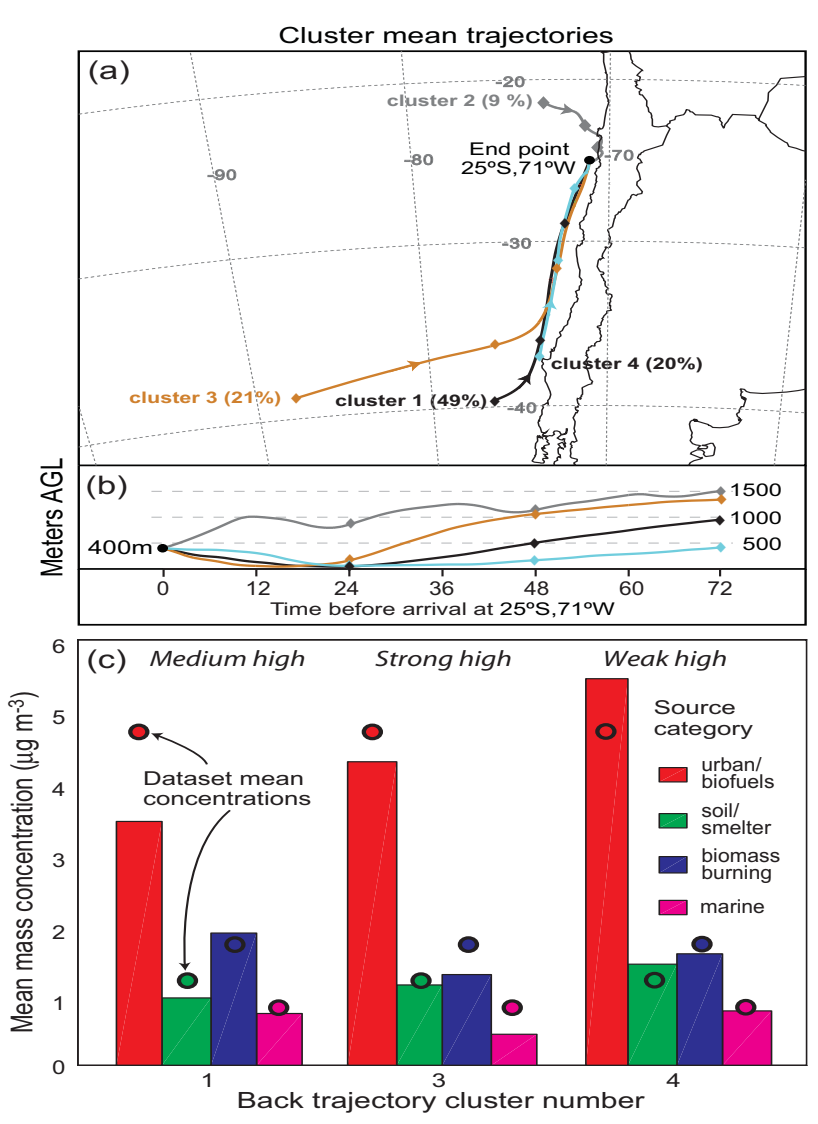

Fig. 10. Mean back trajectories for the four trajectory clusters ending at $400 \mathrm{~m}$ above sea4 level at $2^{\circ} \mathrm{S}, 71^{\circ} \mathrm{W}$ (ocean size just to west of Paposo). A total of 108 back trajectories (72 hour duration) were calculated every $6 \mathrm{~h}$ (ending at 06:00, 12:00, 18:00, 24:00 UTC at $25^{\circ} \mathrm{S}, 71^{\circ} \mathrm{W}$ ) using NCEP GDAS model wind fields (horizontal and vertical). Panel (a) shows the location of the mean trajectories, diamonds indicating $24 \mathrm{~h}$ periods prior to arrival at Paposo. The numbers in parentheses give the percentage of the trajectories that fell into each cluster; (b) height of the mean trajectories with colors corresponding to panel (a); (c) Breakdown of aerosol mass by source category for the three most common clusters (1, 3 and 4). Samples were only included in (c) if the trajectories during the filter sampling period were all from the same cluster. The mean mass concentration for the entire set of filter samples (excluding the first which has an excessive mass loading) are shown as filled circles for comparison.

northerly trajectory cluster 2 (Fig. 10b) which remains well to the north of $30^{\circ} \mathrm{S}$.

Prior to the final $24 \mathrm{~h}$ there are significant differences in the subsidence rate for the southerly trajectories (Fig. 10b), with the slowest cluster (4) associated with the weakest subsidence, and cluster 3 associated with the strongest subsidence. Taken together with the differences in wind speed, the different subsidence rates indicate that trajectory clusters 1,3 and 4 represent different phases during the dominant mode of large scale meteorological variability, namely a strengthening and weakening of the subtropical high. A 
strong subtropical high leads to stronger southerly low-level flow and stronger subsidence (see e.g. Fig. 10 in George and Wood 2010). Thus, trajectory clusters 4,1 and 3 are associated with progressively greater subtropical high pressure strength. The time series showing the cluster to which each trajectory belongs is indicated at the top of Fig. 3 for reference.

Figure 10c shows the aerosol mass loading for the different source categories associated with the southerly trajectory clusters. Since all three of these clusters indicate flow passing the Santiago urban complex, it is perhaps not surprising that the loading profiles look similar to first order. Nevertheless, there are some significant differences. First, the marine mass loading increases from 3 to 1 to 4 , i.e. as the subtropical high strength decreases. This dependency may appear somewhat counterintuitive since one would expect a greater sea-surface source with stronger winds. But the marine mass loading in the MBL is also dependent upon the degree of dilution by entrainment of non-marine air from the free-troposphere, and periods of strong subsidence also tend to be associated with stronger entrainment (Rahn and Garreaud 2010). Entrainment would decrease the mass concentration from marine sources. The source strength and the subsidence/entrainment therefore tend to work in opposite directions, with the result here suggesting a decreased mass loading of the marine source during periods of stronger winds associated with a strong subtropical high.

The mass loading from the urban/biofuels source, which contained the majority of the mass and sulfate, is greatest during periods of weak subtropical high pressure (i.e. trajectory cluster 4 in Fig. 10). This is also true of the smelter/soil dust source. This behavior appears to be consistent with a greater fraction of these trajectories remaining close to the surface over the previous $72 \mathrm{~h}$ (Fig. 10b). The more strongly subsiding trajectories show weaker than average loadings of these pollution sources. Loadings of the biomass burning source, however, more closely resemble the behavior of the marine source in that they are lowest during periods of strong subsidence and are larger during the periods of medium or weak high pressure. Figure 10a shows that the mean trajectories during medium and weak high pressure (clusters 1 and 4) passed close to the Chilean coast around $35-40^{\circ} \mathrm{S}$, whereas the trajectories associated with the strong subtropical high (cluster 3 ) tended to arrive at the coast around $35^{\circ} \mathrm{S}$ before turning northward. According to the MODIS fire detection algorithm, most of the fires in the Chilean lowlands to the west of the Andes during the sampling period occurred in the coastal forests in the latitude range 35$40^{\circ} \mathrm{S}$ (see http://firefly.geog.umd.edu/firemap/), so the mass loadings seem somewhat consistent with the more southerlyextending back trajectories associated with the weaker subtropical high. We do not investigate mass loadings for cluster number 2 since there were no samples made where cluster number 2 was the sole cluster type represented during the sample.
In summary, due to the flow channeling effects of the Andes mountains, most of the air masses arriving at Paposo in the marine boundary layer have a southerly origin. It is also noteworthy that the linkage between the wind speed of the trajectory and the observed concentrations of aerosol species suggests that these aerosol concentrations result from a balance between entrainment and sources along the trajectory. Many of these trajectories will have passed close to major pollution sources including the city of Santiago. Nevertheless it is possible to differentiate, to some extent, the sample composition based on back-trajectory analysis, which appears to reveal a role for the large scale variability in the strength of the subtropical high to modulate the aerosol composition and mass loading at Paposo.

\section{Conclusions}

Submicron aerosol observations were made at an elevated coastal site (Paposo) in the marine boundary layer along the northern Chilean coast during VOCALS-REx to better understand the chemical and physical properties of aerosols originating to the west of the Andes mountain range. These aerosols subsequently advect into offshore regions of the southeastern Pacific where they can interact with the stratocumulus cloud deck. Significant temporal variability is observed in aerosol mass, number concentration, and chemical composition. Sulfate is the dominant resolved soluble species constituting $\sim 40 \%$ of the dry mass, however, $\sim 50 \%$ of the mass was not speciated. Other measurements taken in marine environments downwind of Paposo during VOCALSREx (Hawkins et al., 2010) suggest that in large part this unspeciated mass is organic in nature. Indeed, we find significant contributions to the aerosol mass from soluble organic species, although most of the organic carbon remains undetected by the methodology we employed. Positive Matrix Factorization (PMF) analysis shows that there are four main source categories contributing to submicron aerosol mass, light scattering coefficient, and cloud condensation nucleus (CCN) concentration (the latter inferred from aerosol size distribution measurements). The attributed sources for these aerosols were biomass burning, marine, an urban/biofuels mix and a somewhat ambiguous mix of smelter emissions and mineral dust. The urban/biofuels mix is the most dominant aerosol component, and this source is responsible for much of the sulfate mass. The marine contribution provided only a small overall contribution to mass, $\mathrm{CCN}$ concentration, and scattering. Back trajectory cluster analysis suggests that the dominant variability in the back trajectories is associated with the strength of the subtropical high pressure system, and that variations in this system modulates in somewhat different ways the contributions from marine, pollution and biomass burning sources. The average (mean \pm std) submicron aerosol mass concentration, aerosols light scattering coefficient and aerosol number concentration $(70-280 \mathrm{~nm}$ 
diameter) were, $8.77 \pm 5.40 \mu \mathrm{g} \mathrm{m}^{-3}, 21.9 \pm 11.0 \mathrm{Mm}^{-1}$ and $540 \pm 220 \mathrm{~cm}^{-3}$, respectively. This study suggests that anthropogenic emission of aerosols has the potential to strongly impact both the cloud microphysics and aerosol light scattering in this climate critical region.

Acknowledgements. We are extremely grateful to our colleagues at the Universidad de Chile (especially Laura Gallardo, Rene Garreaud and Ricardo Muñoz, and José Rutllant) and at the Universidad de Valparaiso (Ana Maria Cordova) who located the measurement site at Paposo and coordinated logistics for the measurements to be made. We thank our collaborators Javier Fochesatto and Catherine Cahill and Radovan Krejci for their help with the site preparation, maintenance, and measurements. This work is supported by University of Washington startup funds, NOAA grant NA07OAR4310282, and ONR grant N00014-07$0277 \mathrm{P} 00003$.

Edited by: H. Coe

\section{References}

Allen, G., Coe, H., Abel, S. J., Barrett, P., Clarke, A., Freitag, S., McNaughton, C., Howell, S., Shank, L., Kapustin, V., Brekhovskikh, V., Kleinman, L., Lee, Y.-N., Springston, S., Toniazzo, T., Bretherton, C., Wood, R., George, R., Krecl, P., Brooks, B., McKeeking, G., Bower, K. N., Williams, P. I., Crosier, J., Crawford, I., and Zuidema, P.: Southeast Pacific Boundary Layer Composition and Variability Sampled Along $20 \mathrm{~S}$ During VOCALS-REx, to be submitted to Atmos. Chem. Phys. Discuss., 2010.

Artaxo, P., Fernandes, E. T., Martins, J. V., Yanasoe, M. A., Hobbs, P. V., Maenhaut, W., Long, K. M., and Castanho, A.: Large-scale aerosol source apportionment in Amazonia, J. Geophys. Res., 103, 31837-31847, 1998.

Bates, T. S., Huebert, B. J., Gras, J. L., Griffiths, F. B., and Durkee, P. A.: International Global Atmospheric Chemistry (IGAC) Project's First Aerosol Characterization Experiment (ACE 1): Overview, J. Geophys. Res., 103, 16297-16318, 1998.

Bretherton, C. S., Uttal, T., Fairall, C. W., Yuter, S., Weller, R., Baumgardner, D., Comstock, K., Wood, R., and Raga, G.: The EPIC 2001 stratocumulus study, Bull. Amer. Meteor. Soc., 85, 967-977, 2004.

Bretherton, C. S., Wood, R., George, R. C., Leon, D., Allen, G., and Zheng, X.: Southeast Pacific stratocumulus clouds, precipitation and boundary layer structure sampled along $20 \mathrm{~S}$ during VOCALS-REx, Atmos. Chem. Phys. Discuss., 10, 1592115962, doi:10.5194/acpd-10-15921-2010, 2010.

Chen, L. W. A., Watson, J. G., Chow, J. C., and Magliano, K. L.: Quantifying $\mathrm{PM}_{2.5}$ source contributions for the San Joaquin valley with multivariate receptor models, Environ. Sci. Technol., 41, 2818-2826, 2007.

Cheng, M. D., Hopke, P. K., Barrie, L., Rippe, A., Olson, M., and coauthors: Qualitative determination of source regions of aerosol in Canadian High Arctic, Environ. Sci. Technol., 27, 2063-2071, 1993.

Comstock, K. K., Wood, R., Yuter, S. E., and Bretherton, C. S.: Reflectivity and rain rate in and below drizzling stratocumulus, Quart. J. Roy. Meteorol. Soc., 130, 2891-2919, 2004.
Draxler, R. R., and Rolph, G. D.: HYSPLIT (Hybrid Single-Particle Lagrangian Integrated Trajectory) model, NOAA Air Resources Laboratory, Silver Spring, MD, USA, http://www.arl.noaa.gov/ ready/hysplit4.html, 2003.

Durkee, P. A., Noone, K. J., Ferek, R. J., Johnson, D. W., Taylor, J. P., and coauthors: The impact of ship-produced aerosols on the microstructure and albedo of warm marine stratocumulus clouds: A test of the MAST hypothesis Li and Lii, J. Atmos. Sci. 57, 2554-2569, 2000.

Fitzgerald, J. W.: Dependence of the supersaturation spectrum of $\mathrm{CCN}$ on aerosol size distribution and composition, J. Atmos. Sci., 30, 628-634, 1973.

Furutani, H., Dall'osto, M., Roberts, G., and Prather, K. A.: Assessment of the relative importance of atmospheric aging on $\mathrm{CCN}$ activity derived from field measurements, Atmos. Environ., 42, 3130-3142, 2008.

Gao, S., Hegg, D. A., Hobbs, P. V., Kirchstetter, T. W., Magi, B. I., and Sadelik, M.: Water-soluble organic compounds in aerosols associated with savanna fires in southern Africa: Identification, evolution and distribution, J. Geophys. Res., 108(D13), 8491, doi:10:1029/2002JD002324, 2003.

Garreaud, R. D. and Muñoz, R.: The diurnal cycle in circulation and cloudiness over the subtropical Southeast Pacific: A modeling study, J. Clim., 17, 1699-1710, 2004.

Garreaud, R. D. and Muñoz, R.: The low-level jet off the west coast of subtropical South America: Structure and variability, Mon. Weather Rev., 133, 2246-2261, 2005.

George, R. C. and Wood, R.: Subseasonal variability of low cloud radiative properties over the southeast Pacific Ocean, Atmos. Chem. Phys., 10, 4047-4063, doi:10.5194/acp-10-4047-2010, 2010.

Gidhagen, L., Kahelin, H., Schmidt-Thome, P., and Johansson C.: Anthropogenic and natural levels of arsenic in PM10 in central and northern Chile, Atmos. Environ., 36, 3803-3817, 2002.

Glantz, P., Noone, K. J., and Osborne, S. R.: Scavenging efficiencies of aerosol particles in marine stratocumulus and cumulus clouds, Q. J. Roy. Meteorol. Soc., 129, 1329-1350, 2003.

Gustafsson, O., Krusa, M., Zencak, Z., Sheesley, R. J., Granat, L., Engstrom, E., Praveen, P.,S., Rao, P. S. P., Leck, C., and Rodhe, H.: Brown clouds over south Asia: Biomass or fossil fuel combustion?, Science, 323, 495-498, 2009.

Hawkins, L. N., Russell, L. M., Covert, D. S., Quinn, P. K., and Bates, T. S.: Carboxylic acids, sulfates, and organosulfates in processed continental organic aerosol over the southeast $\mathrm{Pa}$ cific Ocean during VOCALS-REx 2008, J. Geophys. Res., 115, D13201, doi:10.1029/2009JD013276, 2010.

Hegg, D. A., Covert, D. S., and Jonsson, H. H.: Measurements of size-resolved hygroscopicity in the California coastal zone, Atmos. Chem. Phys., 8, 7193-7203, doi:10.5194/acp-8-7193-2008, 2008.

Hegg, D. A., Covert, D. S., Jonsson, H. H., and Woods, R.: Differentiating natural and anthropogenic cloud condensation nuclei in the California coastal zone, Tellus, 61B, 669-676, 2009.

Houghton, J., Ding, T. Y., and Griggs, D. J.: Climate Change 2001, The Scientific Basis, published for the Intergovernmental Panel on Climate Change, Cambridge University Press, Cambridge UK, 881 pp., 2001.

Huneeus, N., Gallardo, L., and Rutllant, J. A.: Offshore transport episodes of anthropogenic sulfur in Northern Chile: Potential im- 
pact on the stratocumulus cloud deck, Geophys. Res. Lett., 33, L19819, doi:10.1029/2006GL026921, 2006.

Jimenez, J., Wu, C.-F., Claiborn, C., Gould, T., Simpson, C. D., Larson, T., and Liu, L.-J. S.: Agricultural burning smoke in eastern Washington - Part I: Atmospheric characterization, Atmos. Environ., 40, 639-650, 2006.

Koponen, I. K., Virkkula, A., Hillamo, R., Kerminen, V.-M., and Kulmala, M.: Number size distributions and concentrations of marine aerosols: Observations during a cruise between the English Channel and the coast of Antarctica, J. Geophys. Res., 107(D24), 4753, doi:10.1029/2002JD002533, 4753, 2002.

Keil, A. and Haywood, J. M.: Solar radiative forcing by biomass burning aerosol particles during SAFARI 2000: A case study based on measured aerosol and cloud properties, J. Geophys. Res., 108, 8467, doi:10.1029/2002JD002315, 2003.

Kelm, U., Helle, S., Matthies, R., and Morales, A.: Distribution of trace elements in soils surrounding the El Teniente copper deposit, Chile: The influence of smelter emissions and a tailing deposit, Environ. Geol., 57, 365-376, 2009.

Kim, E., Hopke, P. K,. Larson, T. V., and Covert, D. S.: Analysis of ambient particle size distributions using Unmix and Positive Matrix Factorization, Environ. Sci. Technol., 38, 202-209, 2004.

Klein, S. A. and Hartmann, D. L.: The seasonal cycle of low stratiform clouds, J. Climate, 6, 1587-1606, 1993.

Kumar, A. and Sarin, M. M.: Mineral aerosols from western India: temporal variability of coarse and fine atmospheric dust and elemental characteristics, Atmos. Environ., 43, 4005-4013, 2009.

Larraín, H., Velasquez, F., Cereceda, P., Espejo, R., Pinto, R., Osses, P., and Schemenauer, R. S.: : Fog measurements at the site Falda Verde north of Chanaral compared with other fog stations of Chile, Atmos. Res., 64, 273-284, 2002.

Martin, G. M., Johnson, D. W., and Spice, A.: The measurement and parameterization of effective radius of droplets in warm stratocumulus clouds, J. Atmos. Sci., 51, 1823-1842, 1994.

Maykut, N. N., Lewtas, J., Kim, E., and Larson, T. V.: Source apportionment of $\mathrm{PM}_{2.5}$ at an urban IMPROVE site in Seattle, Washington, Environ. Sci. Technol., 37, 5135-5142, 2003.

Nicolas, J., Chiari, M., Crespo, J., Orellana, I. G., Lucarelli, F., Nava, S., Pastor, C., and Yubero, E.: Quantification of Saharan and local dust impact in an arid Mediterranean area by the positive matrix factorization (PMF) technique, Atmos. Environ., 42, 8872-8882, 2008.

Paatero, P. and Tapper, U.: Positive Matrix Factorization: A nonnegative factor model with optimal utilization of error estimates of data values, Environmetrics, 5, 111-126, 1994.

Paatero, P., Hopke, P. K., Song, X.-H., and Ramadan, Z.: Understanding and controlling rotations in factor analytic models, Chemom. Intell. Lab. Syst., 60, 253-264, 2002.

Platnick, S. and Twomey, S.: Determining the susceptibility of cloud albedo to changes in droplet concentration with the Advanced Very High Resolution Radiometer, J. Appl. Meteor., 33, 334-347, 1994.

Rahn, D. A. and Garreaud, R.: Marine boundary layer over the subtropical southeast Pacific during VOCALS-REx - Part 2: Synoptic variability, Atmos. Chem. Phys., 10, 4507-4519, doi:10.5194/acp-10-4507-2010, 2010.
Reff, A., Eberly, S. I., and Bhave, P.: Receptor modeling of ambient particulate matter data using Positive Matrix Factorization: Review of existing methods, J. Air \& Waste Manage. Assoc., 57, 146-154, 2007.

Rengarajan, R., Sarin, M. M., and Sudheer, A. K.: Carbonaceous and inorganic species in atmospheric aerosols during wintertime over urban and high-altitude sites in North India, J. Geophys. Res., 112, D21307, doi:10.1029/2006JD008150, 2007.

Russell, P. B, Hobbs, P. V., and Stowe, L. L.: Aerosol properties and radiative effects in the United States east coast haze plume: An overview of the Tropospheric Aerosol Radiative Forcing Observational Experiment (TARFOX), J. Geophys. Res., 104, 2213 2222, 1999.

Shaw, G. E.: Aerosols at a mountaintop observatory in Arizona, J. Geophys. Res., 112, D07206, doi:10.1029/2005JD006893, 2007.

Toledano, C., Cachorro, V. E.. de Frutos, A. M, Torres, B., Berjon, A., Sorribas, M., and Stone, R. S.: Airmass classification and analysis of aerosol types at El Arenosillo (Spain), J. Appl. Meteorol. Climat., 48, 962-981, 2009.

Tomlinson, J. M., Li, R., and Collins, D. R.: Physical and chemical properties of the aerosol within the southeastern $\mathrm{Pa}$ cific marine boundary layer, J. Geophys. Res., 112, D12211, doi:10.1029/2006JD007771, 2007.

Warren, S. G., Hahn, C. J., London, J., Chervin, R. M., and Jenne, R. L.: Global Distribution of Total Cloud Cover and Cloud type Amounts Over the Ocean, NCAR Technical Note NCAR/TN317+STR, 1988 .

Wood, R., Comstock, K. K., Bretherton, C. S., Cornish, C., Tomlinson, J., Collins, D. R., and Fairall, C.: Open cellular structure in marine stratocumulus sheets, J. Geophys. Res., 113, D12207, doi:10.1029/2007JD009371, 2008.

Wood, R., Bretherton, C. S., Mechoso, C. R., Weller, R. A., Huebert, B., Straneo, F., Albrecht, B. A., Coe, H., Allen, G., Vaughan, G., Daum, P., Fairall, C., Chand, D., Gallardo Klenner, L., Garreaud, R., Grados Quispe, C., Covert, D. S., Bates, T. S., Krejci, R., Russell, L. M., de Szoeke, S., Brewer, A., Yuter, S. E., Springston, S. R., Chaigneau, A., Toniazzo, T., Minnis, P., Palikonda, R., Abel, S. J., Brown, W. O. J., Williams, S., Fochesatto, J., and Brioude, J.: The VAMOS Ocean-CloudAtmosphere-Land Study Regional Experiment (VOCALS-REx): goals, platforms, and field operations, Atmos. Chem. Phys. Discuss., 10, 20769-20822, doi:10.5194/acpd-10-20769-2010, 2010.

Wood, R., Köhler, M., Bennartz, R., and O’Dell, C.: The diurnal cycle of surface divergence over the global oceans, Q. J. Roy. Meteorol. Soc., 135, 1484-1493, 2009.

Wyant, M. C., Wood, R., Bretherton, C. S., Mechoso, C. R., Bacmeister, J., Balmaseda, M. A., Barrett, B., Codron, F., Earnshaw, P., Fast, J., Hall, A., Hannay, C., Kaiser, J. W., Kitagawa, H., Klein, S. A., Koehler, M., Manganello, J., Pan, H.-L., Wang, S., and Wang, Y.: The PreVOCA experiment: Modeling the lower troposphere in the Southeast Pacific, Atmos. Chem. Phys., 10, 4757-4774, 2010

Yu, J.-Y. and Mechoso, C. R.: A coupled atmosphere-ocean GCM study of the ENSO cycle, J. Climate, 14, 2329-2350, 2001. 